\title{
EVALUASI PROGRAM PEMBERDAYAAN PEREMPUAN MELALUI PELATIHAN MENJAHIT DI SANGGAR KEGIATAN BELAJAR (SKB) UJUNG PANDANG
}

\author{
NINI PRATIWI ${ }^{1)}$, ILHAM SUPIANA ${ }^{2)}$ \\ STIKS Tamalanrea Makassar \\ ${ }^{1)}$ ninipratiwisabaruddin@gmail.com, ${ }^{2)}$ ilhamstiks@gmail.com
}

\begin{abstract}
ABSTRAK
Berdasarkan hasil data sensus ketenagakerjaan dari Badan Pusat Statistika (BPS), pengangguran pada tahun 2017-2018 mengalami fluktuasi. Pada tahun 2014 TPT laki-laki mengalami penurunan sebesar 1,86 persen dibanding tahun 2013, sementara TPT perempuan justru mengalami peningkatan sebesar 5,6 persen, Oleh karena itu, Program Sanggar Kegiatan Belajar (SKB) dilaksanakan untuk membantu mengurangi tinkgat pengangguran perempuan yang ada di makassar. Penelitian ini bertujuan untuk mendeskripsikan hasil Evaluasi : (1) tingkat kepuasan perserta pelatihan;(2) tingkat pemahaman materi peserta pelatihan ; (3) tingkat Implementasi perilaku peserta pasca pelatihan ; (4) peningkatan keberhasilan pesrta di sebabkan adanya pelatihan.

Penelitian evaluasi menggunakan model Empat Level Kirpatrick yaitu: Level Reaksi, belajar, perilaku, dan hasil. Sampel Penelitian adalah 20 Peserta Alumni Pelatihan.Pengumpulan data menggunakan kuesioner, observasi, dan wawancara tidak terstruktur. Data kuantitatif diolah dengan bantuan SPSS 21.0 for windows. Validitas Instrumen Pada level Reaksi, belajar, perilaku,dan hasil menggunakan Corrected Item-Total Correlation. Perhitungan reliabilitas menggunakan rumus Alpha.

Hasil penelitian menunjukkan: 1). Evaluasi tingkat reaksi kepuasaan pelatihan menjahit terhadap aspek materi, tutor, fasilitas dan metode dalam kategori "PUAS" 2). pemahaman materi peserta pelatihan menjahit terhadap aspek pemahaman materi pelatihan"menguasai", 3). implementasi perilaku peserta pasca pelatihan menjahit terhadap aspek perilaku pasca pelatihan" mengimplementasikan" 4). Evaluasi tingkat hasil mengalami peningkatan oleh adanya pelatihan menjahit mengalami “ kurang peningkatan”.
\end{abstract}

Kata Kunci: Evaluasi, Program Pemberdayaan, Pelatihan,Menjahit.

\section{ABSTRACT}

This study was aimed to describe evaluation results of: (1) participants' level of satisfaction, (2) participants' level of understanding of the material, (3) participants' post-training level of implementation, (4) improved success of participants due to the training.

The research type was evaluation research using Kirkpatrick's Four Level model, which consisted of: Reaction, learning, behavioral, and result levels. The research samples were 20 former training participants. Data was collected by questionnaire, observation, and unstructured interview. Quantitative data was processed with the help of SPSS 21.0 for Windows. Validity of instrument at reaction, learning, behavioral, and result levels used Corrected Item-Total Correlation. Reliability calculation used Alpha formula.

The research result showed that: 1) evaluation of reaction level: the satisfaction to sewing making training in terms of material, tutor, facility, and training method by PAP and PAP was "satisfying" 2) evaluation of learning level: understanding of material of the participants of making training sewing in terms of understanding of training material by PAP and PAN was "Mastering" 3) evaluation of behavioral level: participants' implementation after training sewing of making in terms of post-training behavioral aspect by PAP and PAN was "implementing" 4) evaluation of result level: improved resulting competence due to training sewing of making by PAP and PAN was "poorly improved".

Keywords: evaluation, programempowerment, trainingsewing. 


\section{PENDAHULUAN}

Pendidikan Nonformal meliputi pendidikan kecakapan hidup, pendidikan anak usia dini, Pendidikan kepemudaan, Pendidikan Pemerdayaan Perempuan serta Pendidikan lain yang ditujukan untuk mengembangkan Kemampuan peserta didik( Sistem Pendidikan Nasional No.20 thn 2003 Ayat 1 Pasal 26) Oleh Sebab itu, salah satu peran pendidikan nonformal untuk memberikan pelatihan bagi masyarakat dengan tujuan mampu mengurangi angka penggangguran, meningkatkan motivasi belajar dan memberdayakan masyarakat.

Program pelatihan menjahit merupakan suatu program yang diadakan oleh Sanggar Kegiatan Belajar (SKB) ujung pandang di Provinsi Sulawesi Selatan. Program SKB ujung pandang ini diselenggarakan guna meningkatkan keterampilan perempuan khususnya keterampilan menjahit yang ada di makassar. Program pelatihan yang akan dievaluasi dalam penelitian ini adalah program pelatihan menjahit.

Berdasarkan hasil data sensus ketenagakerjaan dari Badan Pusat Statistika (BPS), pengangguran pada tahun 2017-2018 mengalami fluktuasi. Pada tahun 2014 TPT laki-laki mengalami penurunan sebesar 1,86 persen dibanding tahun 2013, sementara TPT perempuan justru mengalami peningkatan sebesar 5,6 persen, Oleh karena itu, Program Sanggar Kegiatan Belajar (SKB) dilaksanakan untuk membantu mengurangi tinkgat pengangguran perempuan yang ada di makassar. Pelatihan Menjahit dalam program sanggar kegiatan belajar (SKB) ujung pandang tersebut bermaksud untuk meningkatkan keterampilan kinerja Perempuan yang tidak memiliki pekerjaan, Sependapat dengan hal tersebut Trisnawati (2011) Juga memaparkan hasil dari penelitiannya bahwa mudah bagi wanita masuk kepasar kerja dengan pendidikan yang cukup baik dan keterampilan yang memadai.

\section{Rumusan Masalah} adalah:

Berdasarkan latar belakang masalah yang telah dikemukakan di atas, maka rumusan masalah ini

1. Bagaimana hasil evaluasi reaksi peserta pelatihan menjahit dilihat dari aspek materi, tutor, fasilitas, dan metode pelatihan?

2. Bagaimana hasil evaluasi tingkat pemahaman materi pelatihan menjahit dan motivasi oleh pelatihan?

3. Bagaimana hasil evaluasi tingkat implementasi perilaku pasca pelatihan menjahit di tempat kerja maupun praktek kerja di rumah alumni peserta pelatihan?

4. Bagaimana hasil evaluasi tingkat keberhasilan atau dampak program pelatihan menjahit dilihat dari sudut pandang peningkatan kompetensi peserta pelatihan disebabkan oleh adanya dampak pelatihan?

\section{Tujuan Penelitian}

Berdasarkan rumusan masalah di atas, maka penelitian ini bertujuan untuk:

1. Mendeskripsikan reaksi peserta pelatihan menjahit dilihat dari aspek materi pelatihan, fasilitator pelatihan, metode pelatihan, dan fasilitas/sarana prasarana pelatihan.

2. Mendeskripsikan tingkat pemahaman materi pelatihan menjahit dan motivasi

3. Mendeskripsikan tingkat implementasi perilaku pasca pelatihan menjahit di tempat kerja maupun praktek kerja di rumah alumni peserta pelatihan.

4. Mendeskripsikan tingkat keberhasilan atau dampak program pelatihan menjahit dilihat dari sudut pandang peningkatan kompetensi peserta pelatihan disebabkan oleh adanya pelatihan.

\section{METODE PENELITIAN}

Jenis evaluasi yang digunakan dalam penelitian ini dikelompokkan menurut tujuan, metode atau pendekatan, tingkat eksplanasi, dan analisis atau jenis data. Menurut tujuannya penelitian ini termasuk penelitian evaluasi. Apabila dilihat dari pendekatan yang dilakukan, penelitian ini termasuk dalam penelitian Ex Post Facto, yaitu suatu penelitian yang digunakan untuk meneliti peristiwa yang telah terjadi dan kemudian merunut ke belakang untuk menguji faktor-faktor yang dapat menyebabkan timbulnya kejadian tersebut. Apabila dilihat berdasarkan analisis dan jenis datanya, maka penelitian ini adalah penelitian kuantitatif.

Pendekatan kuantitatif digunakan karena adanya pengukuran yang disertai analisis statistik. Sugiyono (2010:11) menjelaskan bahwa pendekatan kuantitatif digunakan dalam evaluasi program untuk 
mengumpulkan, mengelola, dan menyajikan data yang berbentuk angka-angka dengan pengelolaan data yang menggunakan analisis statistik. Kirkpatrick (2008:21) model evaluasi program pelatihan, kirkpatrick tepat digunakan untuk mengetahui program yang dilaksanakan berdampak positif atau negatife sehingga jika program tersebut berdampak positif maka model evaluasi tersebut dapat diguanakn di program yang lain. model evaluasi program Kirkpatrick dapat digunakan pada program pelatihan pendidikan non formal. (Fakhruddin, 2011: 37) " model evaluasi program pelatihan Kirkpatrick cocok digunakan pada pelatihan pendidikan non formal dengan menggunakan empat level, yaitu: 1. Reaksi, 2.Pembelajaran, 3.Tingkah laku, 4.Hasil".

Sugiyono (2015: 117) menyatakan bahwa populasi adalah jumlah keseluruhan Objek yang akan di teliti. Populasi juga diartikan sebagai keseluruhan objek penelitian yang terdiri dari manusia, benda-benda, hewan, tumbuh-tumbuhan, gejala-gejala, nilai tes atau peristiwa-peristiwa sebagai sumber data yang memiliki karakteristik tertentu didalam suatu penelitian. Populasi merupakan kesuluruhan informan yang akan diteliti. Populasi pada penelitian ini adalah seluruh peserta pelatihan menjahit pada tahun 2019 berjumlah 20 orang peserta.

Adapun Instrumen penelitian yang digunakan adalah kuesioner/angket,pedoman observasi berupa lembar checklist, wawancara tidak terstruktur, dan pedoman telaah dokumen. Semua instrumen tersebut dibuat oleh peneliti berdasarkan kerangka konsep dan operasional penelitian. a) Kuesioner digunakan untuk mendapatkan data dari hasil evaluasi pelatihan menjahi, Kuesioner digunakan untuk mendapatkan gambaran evaluasi pelatihan pembuatan baju bodo pada variabel tingkat reaksi, tingkat belajar, tingkat perilaku, dan tingkat hasil program pelatihan. Pada level reaksi, perilaku, belajar dan hasil bentuk kuesioner menggunakan skala likert. Skala likert digunakan untuk mengukur sikap, pendapat dan persepsi seseorang maupun kelompok tentang fenomena sosial (sugiyono, 2010). Dengan menggunakan skala likert,responden diberikan pilihan jawaban dan tingkatan yang positif sampai dengan negatif. Pilihan jawaban tersebut meliputi:

Tabel 1. Alternatif jawaban/skoring

\begin{tabular}{|l|c|c|}
\hline \multirow{2}{*}{\multicolumn{1}{|c|}{ Alternatif Jawaban }} & \multicolumn{2}{c|}{ Skoring } \\
\cline { 2 - 3 } & Jawaban Positif & Jawaban Negatif \\
\hline Sangat Puas/ Selalu/ Sangat Baik & 4 & 1 \\
\hline Puas/ Sering/ Baik & 3 & 2 \\
\hline Tidak Puas/ Kadang-kadang/ Sedang & 2 & 3 \\
\hline Sangat Tidak Puas/ Tidak Pernah/ Rendah & 1 & 4 \\
\hline
\end{tabular}

b). Pedoman observasi menggunakan lembar checklist dibuat oleh peneliti untuk mendapatkan gambaran evaluasi pelatihan pembuatan baju bodo pada lembar checklist tersebut digunakan untuk mengamati kelengkapan perangkat pelatihan. c) Wawancara tidak terstruktur. Untuk mendukung data kuantitatif peneliti juga melakukan wawancara tidak terstruktur dengan responden terkait dengan penelitian evaluasi ini yaitu kepada Kepala SKB, ketua penyelenggara dan tutor. d) Pedoman telaah dokumen dibuat untuk mengumpulkan data ini diperoleh melalui penelaahan dokumen- dokumen terkait dengan pelatihan melalui laporan pelaksanaan program, rekapitulasi peserta pelatihan, dan modul/ materi pelatihan.

\section{HASIL DAN PEMBAHASAN}

Model evaluasi dalam penelitian ini yaitu model Kirkpatrick. Evaluasi pelatihan ini dilakukan berdasarkan empat tingkatan, yaitu evaluasi tingkat reaksi, evaluasi tingkat belajar, evaluasi perilaku dan evaluasi tingkat hasil. Data diperoleh dengan menggunakan kuesioner yang diisi oleh responden. Kuesioner tersebut kemudian dinilai dan dikategorisasikan ke dalam beberapa kelompok. Penilaian dilakukan dalam dua macam, yaitu Penilaian ber-Acuan Patokan (PAP), dan Penilaian ber-Acuan Norma (PAN).

Evaluasi adalah suatu usaha untuk mengukur dan sumber nilai secara objektif dari pencapaian hasilhasil yang direncanakan sebelumnya, dimana hasil evaluasi tersebut dimaksudkan menjadi umpan balik untuk perencanaan yang akan dilakukan di depan (Yusuf, 2010: 3). Evaluasi dilakukan tidak hanya pada suatu organisasi, namun juga dapat dilakukan pada hasil kerja seseorang atau suatu program yang telah diselenggarakan. Evaluasi memiliki tiga fungsi utama, yaitu memberi informasi yang dapat dipercaya mengenai kinerja kebijakan, memberi sumbangan pada klarifikasi dan kritik terhadap capaian tujuan, dan memberi sumbangan pada aplikasi metode analisis kebijakan lain (Wahab, 2015:51).

Evaluasi dapat dilakukan terhadap suatu program. Program merupakan unsur pertama yang harus ada demi tercapainya kegiatan pelaksanaan karena dalam program tersebut telah dimuat berbagai aspek .Unsur 
kedua yang harus dipenuhi dalam pelaksanaan program adalah adanya kelompok orang yang menguji sasaran program.

Penelitian ini melakukan evaluasi terhadap program pelatihan menjahit di SKB Ujung Pandang Kota Makassar. Evaluasi yang dilakukan menggunakan model Kirkpatrick, sehingga terdapat empat hal yang perlu dievaluasi. Keempat hal tersebut, yaitu tingkat reaksi, belajar, perilaku dan hasil.

\section{Evaluasi Tingkat Reaksi}

Evaluasi terhadap reaksi peserta pelatihan berarti mengukur kepuasan peserta (Kirkpatrick, 2008: 21). menjelaskan bahwa ukuran pada level reaksi ini didesain untuk mengetahui opini dari para peserta mengenai program pelatihan. Program pelatihan dianggap efektif apabila proses training dirasa menyenangkan dan memuaskan bagi para peserta pelatihan sehingga mereka tertarik termotivasi untuk belajar dan berlatih. Dengan kata lain, peserta akan termotivasi apabila proses pelatihan berjalan memuaskan bagi peserta yang pada akhirnya akan memunculkan reaksi positif dari peserta yang menyenangkan.

Evaluasi tingkat perilaku peserta pelatihan menjahit untuk setiap komponen evaluasi memperoleh hasil yang berbeda. Pertama, untuk evaluasi produk berdasarkan PAP masuk kategori sangat rendah dengan skor rata-rata sebesar $0.00 \%$ dan berdasarkan PAP masuk kategori sangat tinggi 50.00\%. Kedua, untuk evaluasi tingkat kepuasan berdasarkan PAP masuk dalam kategori tinggi 50.00\% dengan jumlah responden 20 orang.

\section{Evaluasi Tingkat Belajar}

Pada evaluasi hasil belajar (learning measurement) berkaitan dengan pengetahuan yang telah dipelajari, sikap yang telah berubah, dan keterampilan apa yang telah dikembangkan dan diperbaiki Pada tahap ini informasi yang ingin diperoleh adalah untuk mengetahui seberapa jauh para peserta menguasai konsep-konsep, pengetahuan dan keterampilan yang diberikan selama pelatihan. Berdasarkan hasil penelitian evaluasi tingkat belajar peserta pelatihan Menjahit diperoleh hasil skor rata-rata sebagai berikut:

Hasil evaluasi tingkat penguasaan materi pada sikap peserta setelah mengikuti pelatihan berdasarkan PAP yaitu Pada kategori tingkat penguasaan materi sangat baik presentase 55.00\% dan Baik $20.00 \%$, Cukup baik $15.00 \%$, dan kurang baik $10.00 \%$ dengan jumlah responden 20 orang.

\section{Evaluasi Tingkat Perilaku}

Evaluasi pada level ketiga ini berbeda dengan evaluasi terhadap perilaku pada level kedua. Penilaian sikap pada evaluasi level dua difokuskan pada perubahan pengetahuan yang terjadi pada saat kegiatan pelatihan dilakukan sehingga lebih bersifat internal, sedangkan pada penilaian tingkah laku difokuskan pada perubahan tingkah laku setelah peserta kembali di tempat kerja atau praktek kerja di rumah. Apakah perubahan pengetahuan yang telah terjadi setelah mengikuti pelatihan juga akan diimplementasikan melalui tindakan atau perilaku nyata setelah peserta kembali ke tempat kerja atau praktek kerja di rumah sehingga penilaian tingkah laku ini lebih bersifat eksternal. Berdasarkan hasil penelitian evaluasi tingkat perilaku peserta pelatihan menjahit diperoleh hasil skor rata-rata tingkat perilaku perserta pelatihan sebagai berikut. Pada hasil evaluasi tingkat implementasi perilaku ini sangat baik presentase $35.00 \%$, baik $25.00 \%$,cukup baik $15.00 \%$ dan kurang baik $15.00 \%$ dengan jumlah responden 20 orang.

\section{Evaluasi Tingkat Hasil}

Evaluasi hasil dalam level keempat difokuskan pada hasil akhir (final result) yang terjadi karena peserta telah mengikuti suatu program pelatihan (Kirkpatrick, 2008: 21). Yang termasuk dalam kategori hasil akhir dari suatu program pelatihan diantaranya adalah kenaikan produksi, peningkatan kualitas, dan kualitas meningkat. Dengan kata lain adalah evaluasi terhadap impact program. Dalam penelitian ini, pada tingkat hasil difokuskan pada peningkatan kompetensi peserta disebabkan oleh adanya dampak pelatihan menjahit Berdasarkan hasil penelitian evaluasi tingkat hasil peserta pelatihan mejahit diperoleh hasil skor rata-rata tingkat hasil perserta pelatihan sebagai berikut. Hasil evaluasi tingkat dampak pada produksi setelah mengikuti pelatihan berdasarkan PAP, kategori tingkat implementasi perilaku yaitu sangat tinggi $25.00 \%$,tinggi $10.00 \%$,sedang $15.00 \%$, rendah $5.00 \%$ dan sangat rendah $45.00 \%$ dengan jumlah responden 20 orang. 


\section{PENUTUP}

\section{Simpulan}

Berdasarkan hasil penelitian dan pembahasan mengenai evaluasi program pelatihan menjahit, dapat diperoleh kesimpulan sebagai berikut.

1. Hasil evaluasi tingkat kepuasan pelatihan menjahit terhadap aspek materi, fasilitator, metode, dan fasilitas/sarana prasarana pelatihan dengan menggunakan PAP dan PAN masuk dalam kategori "puas".

2. Hasil evaluasi tingkat pemahaman materi peserta pelatihan menjahit terhadap aspek sikap, pengetahuan, dan keterampilan dengan menggunakan PAP dan PAN masuk dalam kategori "menguasai".

3. Hasil evaluasi tingkat implementasi perilaku peserta pasca pelatihan menjahit terhadap aspek sikap, pengetahuan, dan keterampilan dengan menggunakan PAP dan PAN masuk dalam kategori "mengimplementasikan".

4. Hasil evaluasi peningkatan hasil disebabkan oleh adanya pelatihan menjahit dengan menggunakan PAP dan PAN masuk dalam kategori "mengalami kurang peningkatan".

\section{Saran}

1. Keterampilan menjahit membutuhkan pengetahuan melalui pelatihan-pelatihan menjahit.

2. Pengetahuan atau keterampilan menjahit bukan unsur utama penilaian dalam masyarakat, melainkan hasil yang memuaskan merupakan bagian yang utama.

\section{DAFTAR PUSTAKA}

Arikunto. (2010). Evaluation of educational programmes the contribution of history to modern evaluation thinking. Health Science Journal.

Badan Pusat statistik kota Makassar. (2014). Diakses dari https://makassarkota.bps.go.id pada tangga 13 Juni 2020, jam 19.00

Fakhruddin. (2011). Evaluasi program pendidikan nonformal. Semarang: UNNES Press.

Kirkpatrik, Donald. (2008). Evaluating Training Program, The Four Levels. San Fransisco: BerrettKoehler Publisher.

Sugiyono. (2010). MetodePenelitianPendidikan. Bandung: Alfabeta.

Rashid. (2012). The determinant of training effectiveness among organizations receiving services from eksternal training providers Disertasi, The Ohio State University,Ohio. Dissertation Abstracts International, 51, 417.

Topno, H. (2014). Evaluation of training and development: An analysis of various models. IOSR Journal of Business and Management, 5(2), 16-22.

Trisnawati. (2008). Evaluasi program dan instrumen evaluasi (untuk program pendidikan dan penelitian). Jakarta: Rineka Cipta. 